\title{
Research on the Integration of Chinese Excellent Traditional Culture and the Construction of Campus Culture in Colleges and Universities
}

\author{
Yuci Wang \\ Beijing University of Agriculture \\ Beijing, 102206
}

\begin{abstract}
Chinese excellent traditional culture provides rich resources for university to construct the campus culture. What's more, it plays a leading and guiding role in this construction. Constructing campus culture is an important way to develop Chinese traditional excellent culture. In order to carry forward the excellent traditional culture and strengthen the construction of campus culture, the excellent traditional culture should be integrated into the construction of campus material culture, spiritual culture construction, system culture construction, and behavior culture construction, the excellent traditional culture communication platform should be improved and innovated, and the channel of campus culture construction should be broadened.
\end{abstract}

Keywords-Excellent traditional culture; Campus culture in colleges and universities; Integration

\section{INTRODUCTION}

President Xi pointed out in the report of the 19th National Congress of the Communist Party of China that "culture is the soul of a country or a nation. The development of a country is closely related to its culture. When its culture becomes prosperous and flourishing, the country will be likewise flourishing. We won't achieve Chinese great rejuvenation without high cultural confidence and cultural prosperity". Chinese excellent traditional culture is an umbrella term. In this culture, Confucianism and culture represented by Confucius are the main body and in the five millennium's cultural development, it gradually involves all kinds of formed material and intangible culture such as political, economic, ideological, art culture and so on. Chinese excellent traditional culture is our national crystallization of wisdom in the history of five millenniums and is also the essence of Chinese traditional culture definitely settled after experiencing the instability, which has become the foundation for the development of China, profoundly entrenched in everyone's heart, influencing everyone's behavior and thought unconsciously [1].

University campus culture gradually forms in the long-term school practice in which teacher and student are the main body, university campus is the main space and then material, spiritual, institutional and behavioral culture is the main content. University campus culture is the significant component of higher education. And it is the significant way to demonstrate universities' running concept and school characteristics. What's more, it exert a great influence on improving the quality of talented person, deepening higher education reform, facilitating university's development and then, fostering the development of the whole society.

\section{The Significant MeAning of the InTEgRAtion BetweEN ChInESE ExCELlent Traditional CUlture AND UNIVERSITY CAMPUS CULTURE}

\section{A. Excellent Traditional Culture Provides Rich Resources for Universities to Construct Campus Culture}

Chinese excellent traditional culture has a long history, and the humanistic spirit is extensive and profound, condensing the self-disciplined spiritual pursuit and spiritual wealth with never fading charms. It is a foundation for developing an advanced socialist culture and also a backbone for establishing Chinese nation's spiritual home. These excellent traditional cultures provide enriched spiritual food for constructing university campus culture in moral education, intellectual education and physical education. And they have become the base for development and also the resource treasure-house. In view of intellectual education, Chinese excellent traditional culture provides highly cultural richness for constructing university campus culture, involving the Four Books and Five classics, hundred schools of thought, Chu $\mathrm{Ci}$, Han Fu, Han Dynasty classics, Wei Jin metaphysics, Sui Dynasty and Tan Dynasty Buddhism, Tang poem and Song iambic verse, Confucian school of idealist philosophy of the Song and Ming Dynasties, novels of Ming and Qing Dynasties and also the Twenty-Four Histories and Four Great Classic Novels. In addition, it inserts strong humanism atmosphere into university campus and broadens students' horizon and intrigues their cultural confidence. In view of moral education, Chinese nation's traditional ethics has a great influence on Chinese offspring generation from generation and gives the direction for university campus cultural construction and influences students' sentiment in a salutary way. There are many great beliefs and strong wills condensed in Chinese nation's traditional ethics including "being immune to temptations, even though being poor, determined will cannot be changed and never yield to violence", national integrity of "die a martyr to a noble cause", patriotic feelings of "repay the country with supreme loyalty" and "get rid of the Manchus and fulfill the restoration of China", national spirit of "even if when faced with profit, right is always in mind", national spirit of "benevolence and filial piety" and "better a glorious death than 
a shameful life", excellent tradition of "self-discipline and social commitment" and "diligence and self-control", national habits of "believe in honesty and honor the teacher and respect his teaching" and "do boldly what is righteous" and "pragmatic and innovation". From aesthetic education, traditional painting, calligraphy, architecture, sculpture, music, dance, paper-cut, embroidery, QuYi, Kung Fu, costume and folk custom, all of these bring vigor and energy to the university campus cultural construction and also creates an atmosphere for enhancing students' aesthetic judgment.

\section{B. Excellent Traditional Culture Serves as a Leading and Guiding Function in University Campus Cultural Construction}

After experiencing the instability of five millenniums, excellent moral quality, noble national integrity, lofty patriotic spirit and excellent behavior habits all have formed and settled in Chinese excellent traditional culture, which exert a great influence on Chinese nation's ideology, behavior style, ethics and morality, and value pursuit and lead the university campus cultural construction. When establishing university campus culture, we need to take excellent traditional culture as an orientation and practice the core values of socialism, rejecting all awareness and behavior overthrowing Chinese civilization, guarding against abuse and transmission of west wrong thought, which is conducive to making sure that university campus culture has a healthy, positive, civilized and scientific direction and also improving the level and grade of university campus cultural construction.

\section{University Campus Culture Construction is an Important Way to Carry forward and Develop Excellent Traditional Culture}

1) The Main Body in the University Campus Culture Construction is the Main Force for Developing Excellent Traditional Culture

Student and teacher are the main force for building university campus culture. Student is our nation's hope, nation's backbone. Teacher is the disseminator of cultural knowledge, and meanwhile, is also the main force for developing excellent traditional culture. Student is the nuclear force for inheriting and transmitting excellent traditional culture. At present, there are 26.96 million undergraduates in our country. They are reserved forces for constructing our socialism great cause. Therefore, their individual qualities, political consciousness, moral cultivation are intensely concerned with Chinese nation flourishing, and also with the magnificent goal of completing the building of a moderately prosperous society in all respects, and with China dream of Chinese national great rejuvenation. Teacher and student in university have a very important effect on developing Chinese excellent traditional culture, and their emphasis, recognition, understanding and mastery to Chinese excellent traditional culture are closely related to the continuity of inheriting and transmitting Chinese excellent traditional culture and also the tendency of Chinese excellent traditional culture. Therefore, strengthening the university campus culture construction, intriguing student and teacher's enthusiasm about transmitting university campus culture and enhancing their cultural confidence and cultural awareness are favorable for the inheritance and transmission of Chinese excellent traditional culture [2].

2) The Content of University Campus Culture Construction is the Main Platform for Carrying forward Excellent Traditional Culture

The content of university culture construction is colorful, mainly including material culture, institutional culture, spiritual culture and behavioral culture. When constructing campus culture, if we can dig out and take in the content and essence of excellent traditional culture adequately, we will not only propagate and demonstrate Chinese excellent traditional culture in a better way, but also enhance the university's cultural richness and humanism. In the respect of material culture construction, university combines the school environment, infrastructure with excellent cultural tradition. Take harmony as beauty, design a layout in a harmonious way and express will by describing things. In the respect of spiritual culture construction, the choice of the school spirit, the school motto, the school song and the teaching spirit and the leaning spirit are based on classic culture, and also draw lessons from classics. There are too many associations and all kinds of school cultural activities involving national culture association, drama club, choir, music-chess-calligraphy-painting association, literary association, martial arts association, philosophy club, humanity club and also gourmet association, which are all the inheritance and exhibition of excellent traditional culture [3].

3) The Achievement of University Campus Culture Construction has Contribution to the Transmission of Chinese Excellent Traditional Culture.

When constructing university campus culture, if we can deal with Chinese traditional culture in a way in which we take in its essence and get rid of its dross and propagate the positive, elegant respects and resist negative and vulgar respects, good atmosphere for transmitting excellent traditional culture will be created to some extent. The achievement of the university campus culture construction can manifest not only its emphasis on campus culture construction but also the college students' recognition to excellent traditional culture. What's more, university's apparent accomplishment can make more and more students engage in the education of Chinese nation's national ethics, improve students' political awareness and enhance their national spirit and promote their aesthetic judgment and also make them possess cultural awareness and cultural confidence. When in the campus culture construction, university's inheritance and transmission for Chinese excellent traditional culture will not be confined within school and will move to society, and drive more and more people to know and disseminate Chinese excellent traditional culture, making the cultural main melody of the whole society more resonant and cultural confidence manifested, and then enhancing Chinese culture influence and Chinese cultural soft power. 
III. CARRYing Forward Fine Traditional Culture and ENHANCING CAMPUS CULTURE CONSTRUCTION IN COLLEGES AND UNIVERSITIES

\section{A. Excellent Traditional Culture Is Integrated into the Construction of Campus Material Culture, Creating a good Educational Environment}

In terms of material culture construction in universities, the excellent traditional environment of universities should be built firstly. The environment with culture deposits plays an imperceptible role in influencing, edifying and infecting students and teachers so that they can form a positive and healthy characteristics and personalities. The surroundings of the universities can not only be utilized, but also the environment of universities should be planned and distributed reasonably. The technology and humanity of the environment should be taken into consideration in the aspect of layout. The environment, buildings and human should be coordinated. It can represent People Oriented and Unity of Nature and Humanity. The landscaping and greening of environment in universities should be paid more attention so that it can bring a nice experience of viewing pictures when people walk in the universities. Secondly, the material culture facility should be developed and utilized reasonably and the buildings and landscapes can represent excellent traditional culture. The facility, such as the classroom, the lab, the playground, the library, the canteen, the corridor, the road and the square, should satisfy students' needs in studying and living. Meanwhile, it should also take the aesthetic experience into consideration and enhance culture deposits. During the time of planning and layout, the facade of buildings should be emphasized and it should combine with the Chinese fine traditional culture, so as to represent culture needs, culture connotation, culture spirits and culture characteristics and build a better educational environment.

\section{B. Excellent Traditional Culture Is Integrated into the Construction of Campus Spiritual Culture, Promoting the Scientific Development of Campus Culture.}

Campus spiritual cultural construction in university is both the soul and the core of university campus cultural construction and it is also the highest spiritual realm pursued by campus culture construction, and meanwhile it is also the value concept, cultural concept, ideological concept and life concept formed in the long-term teaching practice. And also it is the overall appearance, shown in the teaching spirit, the learning spirit, the school spirit, class spirit and also the relationship among the personnel within the school. In the perspective of building school spirit, the choice and definition of the school song, the school motto, the school badge and school flag and the teaching belief and the managing orientation should manifest the value orientation of excellent traditional culture. What's more, good school spirit has an essential influence on teaching spirit, learning spirit and class spirit and also exerts an intriguing, edified and affected function on student and teacher's thought and behavior. Teaching spirit is a kind of education belief, teaching individuality and also studying attitude, which forms in teachers' long-term work and learn. In addition, it is the comprehensive demonstration concerned with ethics, cultural knowledge and professional knowledge. Learning spirit is the learning attitude, learning habit and leaning method and also behavioral habit, which is shaped in students' long-range studying activities. Only if when the teacher internalizes the strict, responsible, practical and realistic and cooperative teaching spirit and also makes himself be a model of virtue for others can students be led to cultivate the positive, diligent, striving, courteous and elegant learning spirit. Excellent teaching spirit and learning spirit can serve as a leading function for developing school spirit. Only with good school spirit, teaching spirit and learning spirit and with healthy, cooperative, positive and harmonious school atmosphere, and also with a good relationship among all the members in university can teacher and student put adequate enthusiasm and energy into their work and learning. When constructing spiritual culture in university, the connotation of excellent traditional culture should be integrated thus making the science and reasonability of campus culture manifested.

\section{Excellent Traditional Culture Is Integrated into the Construction of Campus Culture, Providing Guarantee for the Construction of Campus culture}

Institutional culture construction of universities is the safeguard mechanism that can keep universities running normally. It includes tradition, rites and all kinds of regulations of universities. The regulation needs to be implemented by human. As a result, the institutional culture construction contains regulation construction and the construction of organization and personnel team. The scientific and effective institutional culture construction is the presupposition of culture construction in universities. Firstly, the managing system of culture construction of universities should be built and improved. The culture construction of universities is significantly important. The leaders of schools and universities constitute managing leading team of campus culture based on the leadership of universities. They should be responsible for culture construction of universities and recruit professional tutors with rich traditional cultural knowledge as the supervisor of culture construction of universities. The tutors should edit books of culture construction, hold education about history and situation of universities, set curriculum about excellent traditional culture and enhance education about excellent traditional culture. In addition, the institutional regulations should be innovated and improved according to the real situation and educational characteristics of universities. All kinds of culture regulations should keep pace with the times and should be innovated constantly based on changes in the characteristics of the times. The tutors and students should obey developing law of excellent traditional culture, develop good character, improve personal quality and ensure smooth process of teaching, research, study and life.

\section{Excellent Traditional Culture Is Integrated into the}

Construction of Campus Behavior Culture, Stimulating the Vitality of Campus Culture Construction.

The construction of the campus behavior culture is the behavior carrier of campus culture, and it is the behavior habit, teaching and scientific research mode, study and life habit, campus cultural activities, community activities and practice 
activities shown by teachers and students in long-term work and study. By integrating the excellent traditional culture into the construction of campus behavior culture, the vitality of campus culture construction can be stimulated. The first one is to carry out colorful traditional culture into campus activities, such as the activities of poetry reading, artistic performances, sports competition, and picture exhibition related to excellent traditional culture, so that students can experience the charm of excellent traditional culture in campus cultural activities. The second one is to establish students' associations based on excellent traditional culture, such as national culture association, painting association, dance association, calligraphy association, martial arts association, drama society, choir, gourmet association and so on, giving policy encouragement and funding support. On the basis of the students' association, we should cultivate a positive and sunny association culture, encourage the association to carry out the cultural activities of the campus with the times and elegant fashion, propagate and display the excellent traditional culture, improve the students' cultural and artistic cultivation and the humanistic quality, so as to improve the grade of the campus culture. The third one is to improve the social practice system of excellent traditional culture. We should encourage students to go out of campus, visit and study local excellent traditional culture and education bases, carry out the commemorative activities of Chinese traditional festivals, let students deeply understand the traditional Chinese culture customs, invite cultural celebrities to carry out famous teachers' lectures, cultivate students' traditional etiquette and civilized habits, and organize students to go to local nursing homes, welfare homes, etc., so that students will understand and appreciate the value and significance of excellent traditional culture more deeply in social practice, and they will be stimulated to be the promoters and inheritors of excellent traditional culture. The fourth one is to advocate scientific spirit and create a strong academic atmosphere. We should establish a good academic and cultural environment, cultivate the awareness of innovation, creative thinking and creative ability of teachers and students, improve the comprehensive quality of students and teachers, and improve the overall cultural quality and level of the school, so as to better inherit and carry forward the excellent traditional culture of China.

\section{E. Improving and Innovating the Excellent Traditional Culture Communication Platform and Broadening the Channel of Campus Culture Construction}

The promotion and inheritance of excellent traditional culture needs certain communication platform. First of all, we should make full use of the functions of traditional communication platform, such as school radio station, TV station, and school newspaper and propaganda column. We can broadcast programs related to excellent traditional culture in radio and TV stations, such as classics reading, traditional art appreciation, etc., set up excellent traditional culture column in the Journal of the school newspaper, and improve the enthusiasm of the students to participate in the inheritance of excellent traditional culture through the activities of student essay contest, photography competition and painting competition, and also carry out the propaganda with excellent traditional culture as the theme on the campus bulletin board combined with traditional festivals and anniversaries every year to improve the enthusiasm and attention of students and teachers to excellent traditional culture. Secondly, we should actively use the new media such as the Internet and mobile phones to expand the communication platform for the excellent traditional culture. With the rapid development of information technology, Internet has become an important communication and learning platform for students and teachers. Colleges and universities can adapt to the development trend of the times, make use of WeChat, micro-blog, QQ, web site, blog, mobile phone APP and other platforms to play the positive energy of the network culture, carry out excellent traditional culture education and socialist core values education, and discuss and exchange the cultural hot spots. We should also explore new teaching models such as Moore and micro lessons, so that students can combine their interests and choose excellent traditional culture courses. Under the background of informatization, the main body of communication is diversified, the means of communication are diversified, the effectiveness of communication is more powerful, and the content of communication is wider. We should make full use of all kinds of communication platforms to broaden the channels for campus culture construction.

\section{CONCLUSIONS}

The excellent Chinese traditional culture provides rich resources for the construction of campus culture, and has the role of leading and guiding. The construction of campus culture in colleges and universities is an important window to carry forward the excellent traditional culture. In order to carry forward the excellent traditional culture and strengthen the construction of campus culture, the excellent traditional culture should be integrated into the construction of campus material culture, spiritual culture construction, system culture construction, and behavior culture construction, the excellent traditional culture communication platform should be improved and innovated, and the channel of campus culture construction should be broadened.

\section{REFERENCES}

[1] Yilin Liu. The Dilemma and Countermeasures of Integrating Chinese Excellent Traditional Culture into Campus Culture[J], China Adult Education, 2017, (20): 65-68. (In Chinese)

[2] Bohao Li and Qiuli Meng. Analysis of the Construction of Campus Culture in Colleges and Universities from the Perspective of Carry ing forward and Inheriting Chinese Excellent Traditional Culture[J], China Adult Education, 2015, (8):70-72. (In Chinese)

[3] Zhibin Cao. On Effective Integration of Excellent Traditional Culture and Campus Culture Construction in Colleges and Universities[J], School Party Building and Ideological Education, 2016, (1): 92-93.(In Chinese) 